\title{
Changing body temperature during aortic arch surgery
}

\author{
Kenji Minatoya, $\mathrm{MD}, \mathrm{PhD}$
}

From the Department of Cardiovascular Surgery, Graduate School of Medicine, Kyoto, Japan.

Disclosures: Author has nothing to disclose with regard to commercial support.

Received for publication Sept 1, 2016; accepted for publication Sept 6, 2016; available ahead of print Sept 30, 2016.

Address for reprints: Kenji Minatoya, MD, PhD, Kyoto University Hospital, 54 Kawaharacho, Shogoin, Sakyo-

ku, Kyoto 606-8507, Japan (E-mail: minatoya@ kuhp.kyoto-u.ac.jp).

J Thorac Cardiovasc Surg 2016;152:1570-1

$0022-5223 / \$ 36.00$

Copyright (C) 2016 by The American Association for Thoracic Surgery

http://dx.doi.org/10.1016/j.jtcvs.2016.09.001

Ever since Griepp and colleagues ${ }^{1}$ reported excellent results in aortic arch replacement with total body hypothermia and circulatory arrest, deep hypothermic circulatory arrest (DHCA) has been used as a standard procedure in aortic arch replacement. The use of selective antegrade cerebral perfusion has empirically revealed that the body temperature during circulatory arrest can safely be raised with this style of perfusion, however, and many institutions worldwide have reported good results in aortic arch replacement with moderate hypothermic circulatory arrest (MHCA). ${ }^{2}$ Raising the body temperature during circulatory arrest has become a trend nowadays in aortic arch replacement; however, the merits of a lesser degree of hypothermia in aortic arch replacement remain unclear. We previously conducted a comparative study of aortic arch surgery at different temperatures and found that although the temperature could be raised safely, there were no definite advantages to doing so. ${ }^{3}$ Thomas and colleagues ${ }^{4}$ reported in a study 209 patients who had undergone aortic arch replacement in the course of a decade and described satisfactory results in aortic arch replacement with DHCA compared with MHCA.

A detailed analysis of a comparison between DHCA and MHCA in aortic arch replacement conducted by Keenan and colleagues $^{5}$ is reported in this issue of the Journal. They used a propensity-matched comparison in hemiarch replacement and concluded that 30-day mortality and morbidity did not significantly differ between the 2 groups. They highlighted their finding that during the surgery the MHCA group required statistically less volume of transfusions and also demonstrated a slight reduction in median volume of blood returned through cell saver and postoperative chest tube output. Unfortunately, the difference was minimal and not clinically appealing. Keenan and colleagues ${ }^{5}$ did demonstrate the safety of performing aortic arch replacement with MHCA, in which the temperature was successfully raised. I commend their sophisticated data analysis.

The same group previously reported excellent results in proximal arch replacement with DHCA. ${ }^{6}$ Although that study population included $36 \%$ of urgent or emergency cases, the 30 -day mortality was only $2.9 \%$, and the rate

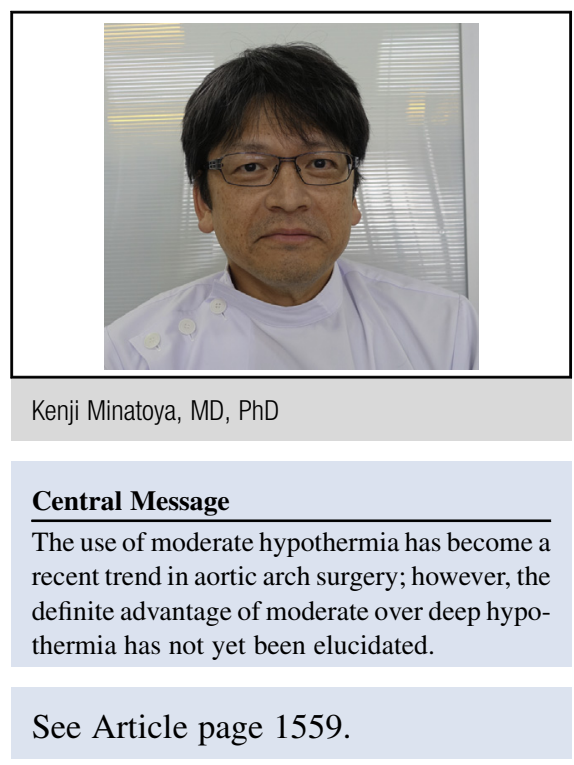

of stroke in elective cases was $0.8 \%$. Accordingly, their report raised questions about the safety of MHCA. Nevertheless, they began to use MHCA in their practice.

Surgeons are eager to raise the body temperature during circulatory arrest because of the risk of coagulopathy in deep hypothermia. A lower temperature requires longer cooling time, and a longer cooling time indicates a longer pump time. A longer pump time in turn leads to a longer duration of operation and may trigger coagulopathy.

We cardiac surgeons have noticed that DHCA is not essential for aortic arch surgery; however, the safe limit of a lesser degree of hypothermia has still not been elucidated. The basis of using the MHCA strategy varies among institutions. In addition, we should be aware that the length of circulatory arrest, site of measurement of body temperature, ways of monitoring various functions, and, most importantly, empirical values differ among institutions. Therefore, as mentioned in the guideline, ${ }^{8}$ institutional experience is an important factor in selecting the strategy for aortic arch replacement, and we should not simply assume that warmer temperature is better than DHCA.

\section{References}

1. Griepp RB, Stinson EB, Hollingsworth JF, Buehler D. Prosthetic replacement of the aortic arch. J Thorac Cardiovasc Surg. 1975;70:1051-63.

2. Tsai JY, Pan W, Lemaire SA, Pisklak P, Lee VV, Bracey AW, et al. Moderate hypothermia during aortic arch surgery is associated with reduced risk of early mortality. J Thorac Cardiovasc Surg. 2013;146:662-7.

3. Minatoya K, Ogino H, Matsuda H, Sasaki H, Tanaka H, Kobayashi J, et al. Evolving selective cerebral perfusion for aortic arch replacement: high flow rate with moderate hypothermic circulatory arrest. Ann Thorac Surg. 2008;86: 1827-31. 
4. Thomas M, Li Z, Cook DJ, Greason KL, Sundt TM. Contemporary results of open aortic arch surgery. J Thorac Cardiovasc Surg. 2012;144:838-44.

5. Keenan JE, Wang H, Gulack BC, Ganapathi AM, Andersen ND, Englum BR, et al. Does moderate hypothermia really carry less bleeding risk than deep hypothermia for circulatory arrest? A propensity-matched comparison in hemiarch replacement. J Thorac Cardiovasc Surg. 2016;152:1559-69.e2.

6. Lima B, Williams JB, Bhattacharya SD, Shah AA, Andersen N, Gaca JG, et al. Results of proximal arch replacement using deep hypothermia for circulatory arrest: is moderate hypothermia really justifiable? Am Surg. 2011;77:1438-44.

7. Okita Y. Surgery for thoracic aortic disease in Japan: evolving strategies toward the growing enemies. Gen Thorac Cardiovasc Surg. 2015;63:185-96. Erratum in: Gen Thorac Cardiovasc Surg. 2015;63:197.

8. Hiratzka LF, Bakris GL, Beckman JA, Bersin RM, Carr VF, Casey DE Jr, et al; American College of Cardiology Foundation/American Heart Associa- tion Task Force on Practice Guidelines; American Association for Thoracic Surgery; American College of Radiology; American Stroke Association; Society of Cardiovascular Anesthesiologists; Society for Cardiovascular Angiography and Interventions; Society of Interventional Radiology; Society of Thoracic Surgeons; Society for Vascular Medicine. 2010 ACCF/AHA/ AATS/ACR/ASA/SCA/SCAI/SIR/STS/SVM Guidelines for the diagnosis and management of patients with thoracic aortic disease. A Report of the American College of Cardiology Foundation/American Heart Association Task Force on Practice Guidelines, American Association for Thoracic Surgery, American College of Radiology, American Stroke Association, Society of Cardiovascular Anesthesiologists, Society for Cardiovascular Angiography and Interventions, Society of Interventional Radiology, Society of Thoracic Surgeons, and Society for Vascular Medicine. J Am Coll Cardiol. 2010;55: e27-129. 